\title{
The impact of digitalization on the Intellectual capital formation and use (case of service enterprises)
}

\author{
Oksana Pirogova ${ }^{1}$, Vladimir Plotnikov ${ }^{2,3, *}$, Ivan Makarov ${ }^{4,5}$, and Andrey Grafov ${ }^{4,5}$ \\ ${ }^{1}$ Peter the Great St. Petersburg Polytechnic University, Polytechnicheskaya str. 29, 195251, \\ St. Petersburg, Russia \\ ${ }^{2}$ Saint-Petersburg State University of Economics, Sadovaya str. 21, 191023, St. Petersburg, Russia \\ ${ }^{3}$ Southwest State University, 50 let Oktiabria str. 94, 305040, Kursk, Russia \\ ${ }^{4}$ Financial University under the Government of the Russian Federation, Lipetsk branch, \\ International'naya str. 12b, 398050, Lipetsk, Russia \\ ${ }^{5}$ The Russian Presidential Academy of National Economy and Public Administration, Lipetsk branch, \\ International'naya str. 3, 398050, Lipetsk, Russia
}

\begin{abstract}
The article discusses the directions, problems and results of using digital solutions in enterprises in the service sector. It is shown that digitalization in the service sector is due to the emergence of a new type of resource - a large amount of specific information about stakeholders. Digitalization has a direct effect on enterprises in the service sector in the form of the development of the institutional environment and the technical infrastructure of digitalization, as well as an indirect action related to the transformation of the enterprises of this industry themselves, their missions and goals. The areas of digitalization in the service sector are indicated. It is shown that the use of digital technologies affects cost reduction and sales growth, and also has a significant impact on the formation and use of the intellectual capital of service enterprises. The features of the formation of the intellectual capital of the enterprise at the stages of the life cycle are considered. The elements of intellectual capital are clarified, which have received an impetus for development due to digitalization. Possible positive directions of the impact of digitalization on the elements of intellectual capital are presented, and the dynamics of the impact of digitalization decisions on the elements of intellectual capital at the stages of the enterprise life cycle is considered.
\end{abstract}

\section{Introduction}

Today, the development of the economy is characterized by the penetration of new digital technologies into all spheres of the economic activity of society. This contributes to the formation of a new information environment for the interaction of economic entities based on the use of information and communication technologies, digital technologies, and big

*Corresponding author: plotnikov_2000@mail.ru 
data technologies. This process is called the process of "digitalization" and has already penetrated quite deeply not only into economic, but also social processes.

The Russian Federation is no exception and belongs to the group of countries in which digitalization is developing at a high pace [1]. Digitalization has a significant impact on the development of individual sectors of the economy, often leading to dramatic changes in the industry, the emergence of new types of activities of economic entities. Currently, the development and implementation of digitalization tools is impossible without the development of technology. The development of digital technologies is focused on two main areas: the restructuring and modernization of the institutional environment (i.e. the normative regulation of digital markets, digital production, digital retail, training personnel with digital competencies, etc.), as well as the development of technical infrastructure (i.e. e-data transmission networks, data centers, software services, etc.), the creation of which requires not only considerable effort, but also investment [2].

The second level of development is the direct development, implementation and development of digital tools in the economy. For example, the use of digital technologies in enterprises in the service sector has led to the emergence of software services, e-commerce, digital manufacturing, and data centers, which occupy a large segment of the market [3].

The purpose of the article is to investigate the impact of digitalization on the formation and use of the intellectual capital of service enterprises. In accordance with this, the objectives of the study include analysis of the impact of digitalization on the enterprise services sector, analysis of the dynamics of the intellectual capital of the enterprise at the stages of the life cycle, identification of aspects of the impact of digitalization on the intellectual capital of enterprises in the service sector [4].

\section{Materials and methods}

Currently, there are four main areas of digitalization in the service sector [5]: the introduction of digital tools for working with consumers, from the stage of interest to the moment of making a purchase, as well as maintaining this interest; the use of digital tools in current activities, which includes work with personnel, goods, price tags, calculations, etc.; carriage of goods, control of supply, storage and sale of goods; ensuring the security system and monitoring the operation of IT infrastructure.

All these areas are aimed at maintaining a wide range of goods and expanding opportunities for the provision of services, as well as creating a logistics system from a supplier to an enterprise in the service sector. Of course, when introducing digitalization tools, certain problems arise, however, these problems are often not currently paid attention to, as evidenced by the results of research in the service sector. So, for example, in the study [6] when evaluating the factors restricting the activity of enterprises in the service sector, there are no digitalization factors, as can be seen in Fig. 1.

Among the factors limiting the activities of service sector organizations, almost half of the survey participants identified weak demand for the services provided, slightly fewer respondents identified the negative impact of a lack of financial resources and a high level of taxation. About a quarter of entrepreneurs included the lack of qualified personnel, unfair competition from other organizations, as well as the uncertainty of the economic situation in the country, among the key problems.

Currently, the development of digital technologies is focused on two main areas: the restructuring and modernization of the institutional environment (regulatory regulation of digital markets, digital production, digital retail, training of personnel with digital competencies, etc.), as well as the development of technical infrastructure (data transmission network, data centers, software services, etc.), the creation of which requires 
not only considerable effort, but also investment [7]. The second level of development is the direct development, implementation and development of digital tools in the economy.

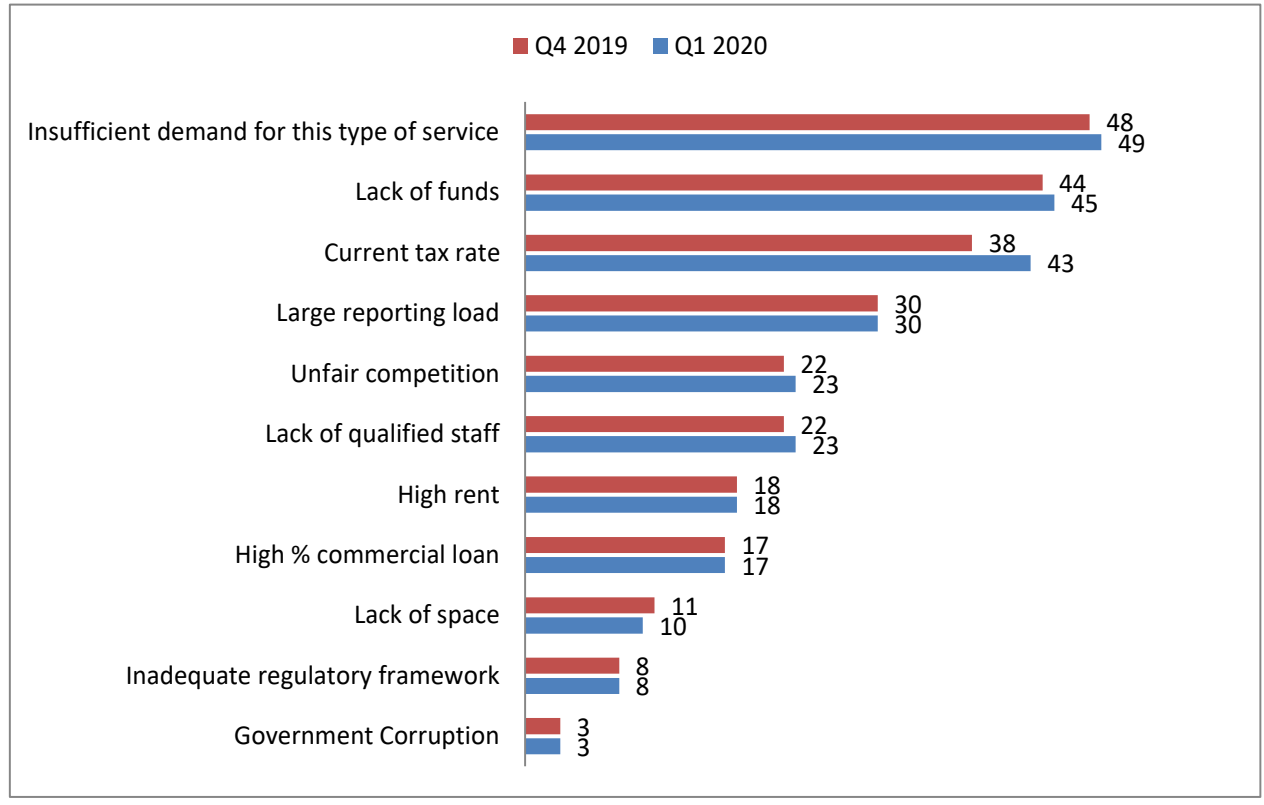

Fig. 1. Estimates of the factors restricting the activity of service enterprises, $\%$ of the number of respondents [8].

Table 1. The positive and negative aspects of the impact of digitalization on the activities of service enterprises.

\begin{tabular}{|l|l|}
\hline $\begin{array}{l}\text { The positive impact of digitalization on the } \\
\text { activities of service enterprises }\end{array}$ & $\begin{array}{l}\text { The negative impact of digitalization } \\
\text { on service enterprises }\end{array}$ \\
\hline $\begin{array}{l}\text { Cost optimization associated with a reduction } \\
\text { in the cost of searching and processing } \\
\text { information, reducing transaction costs, } \\
\text { promotion costs, etc. }\end{array}$ & $\begin{array}{l}\text { Lack of investment in fixed assets } \\
\text { related to the development of the } \\
\text { hardware base of digitalization in the } \\
\text { enterprise services }\end{array}$ \\
\hline $\begin{array}{l}\text { Exclusion of intermediaries. Digitalization } \\
\text { allows service enterprises to independently } \\
\text { promote and advertise their services. }\end{array}$ & $\begin{array}{l}\text { Low government involvement in the } \\
\text { digital economy }\end{array}$ \\
\hline $\begin{array}{l}\text { Reduction of time for market adaptation, } \\
\text { introduction of new products and services }\end{array}$ & $\begin{array}{l}\text { High level of costs (low investment } \\
\text { attractiveness) of the introduction of } \\
\text { digitalization tools in enterprises in the } \\
\text { service sector }\end{array}$ \\
\hline $\begin{array}{l}\text { Accelerating the business processes of service } \\
\text { enterprises }\end{array}$ & $\begin{array}{l}\text { Inadequate security and the risk of } \\
\text { digital fraud }\end{array}$ \\
\hline $\begin{array}{l}\text { Increasing the flexibility and responsiveness } \\
\text { of marketing strategies of service enterprises }\end{array}$ & $\begin{array}{l}\text { Lack of qualified personnel able to } \\
\text { effectively implement and use } \\
\text { digitalization tools in service enterprises }\end{array}$ \\
\hline
\end{tabular}

The effects of the introduction of digitalization elements - economic entities (state, consumers, and enterprises), using digitalization tools, change the behavior model, i.e. their organizational structure, mission and goals are changing, and the speed of these changes is so great that the current level of development of the digitalization infrastructure does not keep pace with the changing economy [7]. The impact of digitalization on the activities of enterprises in the service sector is presented in Table 1. 
Currently, it is noted that the digital infrastructure for service enterprises is growing at a faster pace than the introduction of digital solutions. This trend negatively affects the development of enterprises in the service sector, as digitalization solutions are aimed at developing the intellectual potential and intellectual capital of these enterprises.

Table 2 presents the specific technological advantages and disadvantages in the activities of enterprises in the service sector due to digitalization.

Table 2. Specific technological advantages and disadvantages in the activities of service enterprises due to digitalization.

\begin{tabular}{|l|l|}
\hline $\begin{array}{l}\text { Technological advantages of } \\
\text { digitalization }\end{array}$ & $\begin{array}{l}\text { Technological risks and disadvantages of } \\
\text { digitalization }\end{array}$ \\
\hline $\begin{array}{l}\text { Information sharing and lack of competition } \\
\text { for the use of information }\end{array}$ & $\begin{array}{l}\text { Excessive information openness of the } \\
\text { enterprise increases the risk of opposition in } \\
\text { the competition }\end{array}$ \\
\hline $\begin{array}{l}\text { accumulation of large volumes of data, } \\
\text { implementation of their automatic } \\
\text { processing and analysis }\end{array}$ & $\begin{array}{l}\text { A sharp increase in the volume of } \\
\text { information makes it difficult to find and } \\
\text { evaluate reliability. (noisy effect) }\end{array}$ \\
\hline $\begin{array}{l}\text { Synchronization of information, energy and } \\
\text { material flows, a new level of control over } \\
\text { value chains }\end{array}$ & $\begin{array}{l}\text { Increased risk and increased damage, } \\
\text { increased vulnerability of business } \\
\text { processes to the action of random factors } \\
\text { and factors of intentional impacts }\end{array}$ \\
\hline $\begin{array}{l}\text { The complex effect of the introduction of } \\
\text { new innovative technologies, solutions and } \\
\text { products, the development of technological } \\
\text { intelligence }\end{array}$ & $\begin{array}{l}\text { An avalanche-like increase in the } \\
\text { vulnerabilities of information and digital } \\
\text { networks, and an increase in the level of } \\
\text { cyber fraud }\end{array}$ \\
\hline $\begin{array}{l}\text { The transition from paper to digital } \\
\text { workflow }\end{array}$ & $\begin{array}{l}\text { The need to develop access and } \\
\text { administration systems }\end{array}$ \\
\hline
\end{tabular}

\section{Results}

The concept of intellectual capital arose due to the need to explain the effects of generating benefit and the growth of the total value of an enterprise due to mechanisms and levers that lie outside the financial plane. It turned out that in the framework of the value concept it is impossible to give a full explanation of these phenomena. This entailed the development of the concept of "intellectual capital" - a new construct, or economic category, which was entrusted with the mission of explaining why some companies are doing better and their value is growing at a faster pace than others [9].

An article by T. Stuart «Intellectual capital - the main wealth of your company» played a decisive role in the dissemination of this term [10]. The study of intellectual capital is a new direction in enterprise management. Many researchers currently consider intellectual capital as an element of capital, which forms a growth in value due to the management of factors that cannot be attributed to operational or financial. Investments in intellectual capital are considered from the perspective of investments, i.e. investments with a certain level of return, but the return is not direct, but indirect.

Intellectual capital has several features, among which are:

- the presence of a higher degree of development, in comparison with the already known forms of capital;

- development of intellectual capital already on existing forms of capital;

- intellectual capital resources are not additive (that is, the value of a quantity corresponding to the whole object is equal to the sum of the values of the quantities corresponding to its parts, for any partition of the object into parts);

- intellectual capital embodied in skills, experience, knowledge accumulates over time; 
- as it accumulates, the return on intellectual capital increases (i.e. investing in intellectual capital should bring greater returns than invested in it);

- investments in this type of capital give a strong in volume and long-term economic and social effect;

- intellectual capital is almost completely illiquid, since it cannot be separated from a person;

- the functioning of intellectual capital is determined by individual interests, preferences, worldview, etc.

Currently, the most common is the model of intellectual capital, which consists of three components: human capital, structural capital, consumer capital. One of the directions of development in understanding the role of intellectual capital is an approach based on theories of the life cycle of an enterprise. In accordance with this approach, the enterprise goes through several stages in its development.

On the one hand, these stages can be represented in the form of certain stages. From the point of view of the enlarged analysis, one can distinguish the stages of emergence, rapid growth, maturity and the stage of bifurcation, when the development of the enterprise can go either in the direction of its further growth in value in the case of creating new values for customers and stakeholders, or take the path of decay when the quality of meeting needs customers will decline [11].

At the stage of origin (birth), the materialization and institutionalization of a business idea takes place and its design in the form of a working mechanism. The main component of intellectual capital at this stage is human capital, as a set of entrepreneurial abilities of the organizer, as well as his associates. Other types of intellectual capital - structural and consumer at this stage are still missing. It is thanks to human capital that the volume of knowledge and experience of individuals who united when creating the enterprise into a team is processed into a certain structure, thanks to which real investments get the opportunity to pay off in the future. If at this stage it is not possible to form human capital, then the enterprise will fail.

At the stage of rapid growth, collegiality is manifested largely; the company develops its mission, strategy and goals. At this stage, the rules for the interaction of various members of the labor collective are formalized. Elements of the cultural environment of the enterprise are being accumulated. At this stage, organizational capital is formed. Also at this stage consumer capital begins to form, however, to a lesser extent than organizational capital. Human capital continues its development in terms of clarifying the qualifications of various employees of the enterprise.

The next stage is the maturity stage. At this stage, consumer capital is fully formed. The existing organizational structure and competencies of employees and managers of the enterprise make it possible to use the mechanisms of interaction with the consumer as efficiently as possible in order to increase loyalty and, as a result, increase revenue.

The next stage of development is characterized by a dual opportunity. After the maturity stage, the stage of aging or decline may occur. This is because the prevailing human and organizational capital cease to provide the previous efficiency of activity, i.e. the degradation of these elements of intellectual capital begins. In the end, this can lead to the destruction of consumer capital. However, if the management of the enterprise manages to find new niches, re-engineer business processes, then the company can get a second wind and the stage of development of elements of intellectual capital will be repeated [12].

\section{Discussion}

Analysis of the main areas of digitalization in the service sector allows us to identify the following areas of impact: digitalization of interaction with the buyer or consumer of 
services; digitalization of value and value chain management; digitalization of the operational activities of employees of service enterprises. As noted above, these areas are designed to solve the following trends - differentiation, new sources of income, cost reduction [13]. The components of the individual components of intellectual capital, and the factors of digitalization that affect intellectual capital, are presented in Table 3.

Table 3. Elements of intellectual capital, developed through digitalization.

\begin{tabular}{|c|c|c|}
\hline & Elements of intellectual capital & Digitalization Elements \\
\hline & $\begin{array}{l}\text { Knowledge } \\
\text { Skills } \\
\text { Experience and length of service } \\
\text { Creative skills } \\
\text { Moral values } \\
\text { Culture of Labor and Organizational } \\
\text { Relations } \\
\text { Physical and Mental Health }\end{array}$ & $\begin{array}{l}\text { Knowledge and skills of using } \\
\text { specialized software } \\
\text { Willingness to master and use in the } \\
\text { work of new types of software and new } \\
\text { devices that increase the level of } \\
\text { digitalization }\end{array}$ \\
\hline 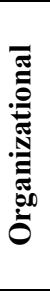 & $\begin{array}{l}\text { Hardware and software } \\
\text { Database } \\
\text { Patents } \\
\text { Trademarks } \\
\text { Organizational structure } \\
\text { Organization culture } \\
\text { Organizational standards, norms, } \\
\text { regulations }\end{array}$ & $\begin{array}{l}\text { Hardware and software } \\
\text { Databases providing operational } \\
\text { activities } \\
\text { Organizational forms and structures, } \\
\text { standards, norms, regulations, focused on } \\
\text { the use of digital solutions } \\
\text { A corporate culture that incorporates the } \\
\text { use of digital solutions }\end{array}$ \\
\hline 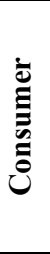 & $\begin{array}{l}\text { Partner Relations } \\
\text { Customer Relations } \\
\text { Customer Information } \\
\text { Customer Relationship History } \\
\text { Trademark (brand) }\end{array}$ & $\begin{array}{l}\text { Customer Databases } \\
\text { Own Internet solutions, customer } \\
\text { interaction platforms } \\
\text { Databases about suppliers } \\
\text { Means of digital communication with } \\
\text { stakeholders (advertising, public } \\
\text { relations), etc. }\end{array}$ \\
\hline
\end{tabular}

Even a cursory analysis shows that the activities of enterprises in the service sector in the field of digitalization are aimed at improving the efficiency of the return of elements of intellectual capital but using digital solutions. Possible positive impacts of the areas of digitalization of service enterprises on the elements of intellectual capital are presented in Table 4.

Table 4. Possible positive impacts of the areas of digitalization of service enterprises on the elements of intellectual capital.

\begin{tabular}{|l|c|c|c|}
\hline & $\begin{array}{c}\text { Differentiation } \\
\text { (DF) }\end{array}$ & $\begin{array}{c}\text { New Sources of } \\
\text { Income (IS) }\end{array}$ & $\begin{array}{c}\text { Cost Reduction } \\
\text { (CR) }\end{array}$ \\
\hline Human capital & & + & + \\
\hline $\begin{array}{l}\text { Organizational } \\
\text { capital }\end{array}$ & & + & + \\
\hline Consumer capital & + & + & \\
\hline
\end{tabular}

The data presented in Table 2 show the directions of concentration of efforts of service enterprises in the management of intellectual capital, make it possible to correctly implement digital tools, taking into account, on the one hand, the complexity of the approach (it is necessary to introduce digitalization elements in several directions at once), and on the other hand, timeliness when there is the feasibility of developing one or another element of intellectual capital at this stage of the life cycle of a service industry enterprise $[14,15]$. 
For a more reasonable and effective investment in the elements of intellectual capital presented Table 4 can be specified for various stages of the enterprise life cycle. Options for such refinement are presented in Fig. 2.

The proposed approach allows you to build the optimal path of development of the intellectual capital of a service industry enterprise, depending on the stage of the life cycle, taking into account the possibility of formation and development of elements of intellectual capital at this stage of development. The proposed matrices also make it possible to coordinate enterprise development programs, including those aimed at introducing digitalization tools, with objective opportunities for the formation and accumulation of intellectual capital of a service industry enterprise.

\begin{tabular}{|c|c|c|c|}
\hline \multicolumn{4}{|c|}{ Stage of occurrence } \\
\hline & DF & IS & CR \\
\hline $\mathrm{HC}$ & & + & \\
\hline \multicolumn{4}{|l|}{ OC } \\
\hline $\mathrm{CC}$ & & & \\
\hline
\end{tabular}

\begin{tabular}{|c|c|c|c|}
\hline \multicolumn{4}{|c|}{ Maturity stage } \\
\hline & DF & IS & CR \\
\hline HC & & & + \\
\hline OC & & & + \\
\hline CC & + & + & \\
\hline \multicolumn{3}{|c|}{} \\
\hline
\end{tabular}

\begin{tabular}{|c|c|c|c|}
\hline \multicolumn{5}{|c|}{ Rapid growth stage } \\
\hline & DF & IS & CR \\
\hline HC & & & \\
\hline OC & & & + \\
\hline CC & + & & \\
\hline
\end{tabular}

\begin{tabular}{|c|c|c|c|}
\hline \multicolumn{4}{|c|}{ Stage of decline } \\
\hline & DF & IS & CR \\
\hline HC & & + & \\
\hline OC & & + & \\
\hline CC & & + & \\
\hline \multicolumn{4}{|c}{} \\
\hline
\end{tabular}

Fig. 2. The dynamics of rational combinations of factors of digitalization and the development of elements of intellectual capital of the enterprise services.

\section{Conclusion}

Thus, intellectual capital is a rather complex type of capital, which has an ambiguous structure and degree of influence on the results of the enterprise, and requires special approaches to its formation and use, based on its economic nature. It is shown that digitalization has both a direct effect on enterprises in the service sector in the form of the development of the institutional environment and technical infrastructure, and an indirect effect related to the transformation of the enterprises of this sphere themselves, their missions and goals.

The article presents the possible directions of the impact of digitalization of service industry enterprises on the structural elements of intellectual capital and considers possible options for effective investment in intellectual capital elements for various stages of the life cycle of service enterprises.

The study was supported by a grant from the President of the Russian Federation on state support of leading scientific schools of the Russian Federation NSh-2702.2020.6 "Conceptual foundations of a new paradigm of economic development in the era of technological and social transformation". 


\section{References}

1. V.A. Plotnikov, Digitalization of production: theoretical essence and development prospects in the Russian economy, News of St. Petersburg State University of Economics 4(112), 16-24 (2018)

2. O. Pirogova, M. Makarevich, O. Ilina, V. Ulanov, Optimizing trading company capital structure on the basis of using bankruptcy logistic models under conditions of economy digitalization, IOP Conference Series: Materials Science and Engineering 012129 (2019)

3. I. Aleksandrov, M. Fedorova, Digital economy and green economy: rural unemployment and territorial self-development in Russia (2019) doi: 10.1051/e3sconf/201911002019

4. V.I. Ananyin, K.V. Zimin, R.D. Gimranov, M.I. Lugachev, K.G. Skripkin, Real time enterprise management in digitalization 1(13), 7-17 (2019)

5. A. Rappaport, Corporate performance standards and shareholder value, Journal of Business Strategy 2, 14-28 (1986)

6. J. Stern, G. Stewart, D. Chew, The EVA Financial Management System Journal of Applied Corporate Finance 8 (2), 32-46 (1995) DOI: 10.1111/j.17456622.1995.tb00285.x.

7. V.A. Makovkina, I.A. Semeykina, Organization of interaction with stakeholders as a factor in increasing the efficiency of corporate governance, Bulletin of the University (GUU) 7-8, 235-239 (2016)

8. V. Plotnikov, O. Pirogova, Key Competencies as an Enterprise Value Management Tool, Proceedings of the 31st International Business Information Management Association Conference (IBIMA) «Innovation Management and Education Excellence through Vision» 1716-1721 (2018)

9. I.B. Gurkov, Conditions for the sustainable development of a commercial company 3(54), 100-114 (2011)

10. I.B. Gurkov, E.M. Avraamova, Russian companies looking for a way to sustainable development, Economic Issues 6 138-148 (2011)

11. O. Pirogova, V. Plotnikov, The model of commercial enterprise value managing (strategic level), Proceedings of the 33rd International Business Information Management Association Conference, IBIMA «Education Excellence and Innovation Management through Vision» 928-935 (2019)

12. R.E. Freeman, Strategic management: A Stakeholder approach (Boston: Pitman, 1984)

13. J.S. Harrison, St. John, Strategic management of organizations and stakeholders: concepts and cases (Cincinnati: South-Western College Publishing, 1998)

14. L.E. Greiner, Evolution and Revolution as Organizations Grow, Harvard Business Review 50 (4), 37-46 (1972)

15. I.V. Ivashkovskaya, Modeling the value of the company, Strategic responsibility of the board of directors (INFRA-M, Moscow, 2009) 